\title{
Investigation of thin perovskite layers between cathode and doped ceria used as buffer layer in solid oxide fuel cells
}

\author{
Aleksander Chrzan • Jakub Karczewski • Maria Gazda • \\ Dagmara Szymczewska • Piotr Jasinski
}

Received: 12 December 2014 / Revised: 2 March 2015 / Accepted: 4 March 2015 /Published online: 24 March 2015

(C) The Author(s) 2015. This article is published with open access at Springerlink.com

\begin{abstract}
In this paper, thin perovskite layers between cathode material of solid oxide fuel cells and gadolinia-doped ceria buffer layer are investigated. Thin layers made of $\mathrm{LaNi}_{0.6} \mathrm{Fe}_{0.4} \mathrm{O}_{3-\delta}$ (LNF), $\mathrm{La}_{0.6} \mathrm{Sr}_{0.4} \mathrm{Co}_{0.2} \mathrm{Fe}_{0.8} \mathrm{O}_{3-\delta}$ (LSCF), or $\mathrm{SrTi}_{0.65} \mathrm{Fe}_{0.35} \mathrm{O}_{3-\delta}$ (STF) were symmetrically deposited by spin coating method from metallo-organic polymer precursors on a $\mathrm{Ce}_{0.8} \mathrm{Gd}_{0.2} \mathrm{O}_{2-\delta}$ (CGO) substrate. Porous and about $40-\mu \mathrm{m}$-thick LNF cathodes were deposited on both sides of the substrate and sintered at $1100{ }^{\circ} \mathrm{C}$. Different thicknesses of the thin perovskite layer were investigated in order to find the most effective one and to better understand its influence on the cathode/electrolyte interface. It was found that approximately $150 \mathrm{~nm}$ LNF or LSCF layer is sufficient to minimize interface resistance and improve cathode reproducibility. It was concluded that the thin perovskite layer increases contact area and improves the oxygen ion transport between the cathode and electrolyte without influencing the oxygen reduction reaction mechanism.
\end{abstract}

Keywords Perovskite layer $\cdot$ Thin film $\cdot$ Cathode $\cdot$ Solid oxide fuel cell

\section{Introduction}

Fuel cells are devices that directly convert chemical energy into electricity. As a result, they are not limited by the

A. Chrzan $(\bowtie) \cdot$ D. Szymczewska $\cdot$ P. Jasinski

Faculty of Electronics, Telecommunications and Informatics, Gdansk

University of Technology, Narutowicza 11/12,

80-233 Gdansk, Poland

e-mail: aleksander.chrzan@eti.pg.gda.pl

J. Karczewski • M. Gazda

Faculty of Applied Physics and Mathematics, Gdansk University of

Technology, Narutowicza 11/12, 80-233 Gdansk, Poland
Carnot cycle, therefore can achieve high efficiency. Also, utilization of hydrogen as a fuel implicates the lack of $\mathrm{CO}_{2}$ and other pollutant emission. The ones of the most promising types of fuel cells are solid oxide fuel cells (SOFC). They have high efficiency, they can be fueled by either hydrogen or hydrocarbons and do not include any moving parts, which might reduce durability [1]. SOFCs usually consist of ceramic or cermet, porous electrodes separated by a dense, oxide-ion conducting ceramic membrane, usually made of yttria-stabilized zirconia (YSZ). Using such materials implies the main SOFC feature-high-temperature operation. Traditional, hightemperature fuel cells provide sufficient power density above $800{ }^{\circ} \mathrm{C}$. It is crucial to lower operation temperature to medium-temperature range $\left(600-800{ }^{\circ} \mathrm{C}\right)$. This enables usage of less expensive materials, lowers thermal stress, shortens start-up and shut-down time, and reduces number of possible unwanted chemical reactions between fuel cell components [2]. On the other hand, lower temperature decreases both conductivity and catalytic activity of fuel cells, especially cathodes [3,4]. Therefore, there is ongoing search for novel cathode materials exhibiting an improved performance at temperatures below $800{ }^{\circ} \mathrm{C}$ [4-6]. Apart from an appropriate chemical composition of the cathode, it is also important to properly adjust the microstructure, especially of the cathode/electrolyte interface [7-10]. As a result, it became a common practice to incorporate of at least $10-\mu \mathrm{m}$-thick cathode functional layer, which has a finer microstructure than a cathode current collector layer [11]. The justifiability of such a layer was also proven theoretically [12]. Recently, much thinner functional layers between the cathode/electrolyte were found to improve fuel cell performance. Such a layer has been prepared by dip-coating ( $2 \mu \mathrm{m}$ thick) by Rieu [13] and by screen printing ( $5 \mu \mathrm{m}$ thick) by Woolley [14], and it decreased polarization resistance of a $\mathrm{La}_{2} \mathrm{NiO}_{4+\delta}$ 
electrode. Hildenbrand reported an improvement of the cathode/electrolyte interface for $\mathrm{La}_{0.6} \mathrm{Sr}_{0.4} \mathrm{Co}_{0.2} \mathrm{Fe}_{0.8} \mathrm{O}_{3-\delta}$ (LSCF) and $\mathrm{La}_{2} \mathrm{NiO}_{4+\delta}$ cathodes using a thin dense layer obtained by pulsed laser deposition $[15,16]$. Recently, Dumaisnil investigated a spin-coated 700-nm-thick LSCF layer between a $\mathrm{Ce}_{0.9} \mathrm{Gd}_{0.1} \mathrm{O}_{2-\delta}$ electrolyte and an LSCF cathode [17]. Previous studies focused on cathodes with high ionic conductivity and dense layers made of the same material. None of primary electronically conductive cathode materials has been studied so far. Therefore, it is substantial to establish if the thin perovskite layer can also improve properties of a cell with the predominantly electronic conducting cathode. This issue was addressed in this paper. Namely, the $\mathrm{LaNi}_{0.6} \mathrm{Fe}_{0.4} \mathrm{O}_{3-\delta}$ (LNF) cathodes with the thin perovskite layers of different types of conductivity, i.e., LNF, LSCF, and $\mathrm{SrTi}_{0.65} \mathrm{Fe}_{0.35} \mathrm{O}_{3-\delta}$ (STF), were investigated. LNF is a mixed ionic-electronic conductor with relatively low ionic conductivity and a promising cathode or current collector material due to a moderate stability in the presence of chromia [18, 19]. LSCF is a state-of-the-art mixed ionic-electronic conductor $[4,5]$. STF is a much weaker electronic conductor but exhibits higher ionic conductivity and the order of magnitude higher surface exchange coefficient [20]. Table 1 lists ionic and electronic conductivities of these perovskites at $800{ }^{\circ} \mathrm{C}$.

Thin perovskite layers were fabricated using spin coating of a metallo-organic precursor. This method is well suited for a large-scale production and enables an easy control over the layer thickness. The thickness of the thin perovskite layer was also altered, i.e., from about 25 to $400 \mathrm{~nm}$, in order to find the most efficient one. To deposit and investigate thin perovskite layers, a $\mathrm{Ce}_{0.8} \mathrm{Gd}_{0.2} \mathrm{O}_{2-\delta}$ (CGO) support was used. $\mathrm{CGO}$ is often used as an electrolyte instead of YSZ [26]. It is also employed as a buffer layer preventing reactions between zirconium from YSZ electrolyte and strontium or lanthanum from certain cathodes, for example LNF [27]. Thin perovskite layers made of LNF and STF were studied for the first time.

\section{Experimental}

In order to evaluate the cathode/buffer layer interface, symmetrical cells with two LNF electrodes were prepared on a gadolinia-doped ceria (CGO) substrate. The substrates were prepared from the CGO powder (GDC-20 K, Daiichi Kigenso Kagaku Kogyo), which was uniaxially pressed under a pressure of $100 \mathrm{MPa}$ and sintered at $1350{ }^{\circ} \mathrm{C}$ for $4 \mathrm{~h}$. Obtained pellets were $1 \mathrm{~mm}$ thick and had a diameter of $13 \mathrm{~mm}$. The measured density of pellets was $99 \%$ of the theoretical, which was enough to prevent spin-coated precursor from infiltrating the substrate.

Three different thin perovskite layers, i.e., $\mathrm{LaNi}_{0.6} \mathrm{Fe}_{0.4} \mathrm{O}_{3-\delta}$ (LNF), $\mathrm{La}_{0.6} \mathrm{Sr}_{0.4} \mathrm{Co}_{0.2} \mathrm{Fe}_{0.8} \mathrm{O}_{3-\delta}$ (LSCF), and $\mathrm{SrTi}_{0.65} \mathrm{Fe}_{0.35} \mathrm{O}_{3-\delta}(\mathrm{STF})$, were prepared by spin coating of
Table 1 Electronic and ionic conductivities at $800{ }^{\circ} \mathrm{C}$ of perovskites used for thin film fabrication

\begin{tabular}{llll}
\hline Material & $\sigma_{\text {el }}\left[\mathrm{S} \mathrm{cm}^{-1}\right]$ & $\sigma_{\text {ion }}\left[\mathrm{S} \mathrm{cm}^{-1}\right]$ & Ref. \\
\hline $\mathrm{LaNi}_{0.6} \mathrm{Fe}_{0.4} \mathrm{O}_{3-\delta}$ & $200-700$ & $7 \times 10^{-5}$ & {$[21-23]$} \\
$\mathrm{La}_{0.6} \mathrm{Sr}_{0.4} \mathrm{Co}_{0.2} \mathrm{Fe}_{0.8} \mathrm{O}_{3-\delta}$ & $280-330$ & $8 \times 10^{-3}$ & {$[4,5,24,25]$} \\
$\mathrm{SrTi}_{0.65} \mathrm{Fe}_{0.35} \mathrm{O}_{3-\delta}$ & 0.99 & $3.5 \times 10^{-2}$ & {$[20]$} \\
\hline
\end{tabular}

polymer precursors. The precursors were prepared by a modified Pechini method [28] by mixing ethylene glycol, citrate acid, and appropriate metal nitrates $\left(\mathrm{La}\left(\mathrm{NO}_{3}\right)_{3} \times 6 \mathrm{H}_{2} \mathrm{O}\right.$, $\mathrm{Ni}\left(\mathrm{NO}_{3}\right)_{2} \times 6 \mathrm{H}_{2} \mathrm{O}, \mathrm{Fe}\left(\mathrm{NO}_{3}\right)_{3} \times 9 \mathrm{H}_{2} \mathrm{O}, \mathrm{Sr}\left(\mathrm{NO}_{3}\right)_{2}, \mathrm{Co}\left(\mathrm{NO}_{3}\right)_{2} \times$ $6 \mathrm{H}_{2} \mathrm{O}$ ), or titanium(IV)butoxide (all Sigma-Aldrich) using molar ratio of 40:2.2:1, respectively. In order to increase wetting properties and control viscosity, 2-ethoxyethanol was added to the solution. The precursors were spin coated on polished CGO pellets for $2 \mathrm{~min}$ at $2500 \mathrm{rpm}$. After every deposition samples were fired at $500{ }^{\circ} \mathrm{C}$ on a hot plate. At this point, the deposited films were dense, and their thicknesses were calculated based on a sample weight change and later confirmed by a SEM examination. Each of the spin coating process (deposition of about $30 \mu \mathrm{l}$ of precursor) produced layer approximately $24 \mathrm{~nm}$ thick for LNF and $27 \mathrm{~nm}$ thick for LSCF and STF. The precursor compositions and the spin coating parameters were chosen experimentally based on film morphology.

Round cathodes with a diameter of $7 \mathrm{~mm}$ were brush painted on the thin perovskite layers using a $\mathrm{LaNi}_{0.6} \mathrm{~F}_{0.4} \mathrm{O}_{3-\delta}$ paste obtained from Energy Research Centre of the Netherlands, Petten. To obtain the reproducible and flat cathode, the painting was repeated three times. The amount of paste was controlled by weight in order to deposit approximately $40-\mu \mathrm{m}$-thick layers. Cathodes were sintered at $1100^{\circ} \mathrm{C}$ for $2 \mathrm{~h}$. Lower sintering temperatures provided layers which could be easily delaminated. Platinum current collector layers, about $5 \mu \mathrm{m}$ thick, were brush painted (ESL 5542) on LNF cathodes and sintered at $900{ }^{\circ} \mathrm{C}$ for $2 \mathrm{~h}$. Schematic representation of a sample is shown in Fig. 1. In order to determine the reproducibility of the results, each arrangement has been prepared at least three times.

Structural information was obtained using X-ray diffractometry (Philips X'Pert Pro) with $\mathrm{Cu} \mathrm{K} \alpha$ radiation at room temperature. Sample morphology was determined by scanning electron microscopy (SEM, Quanta $250 \mathrm{FEI}$ ) and atomic

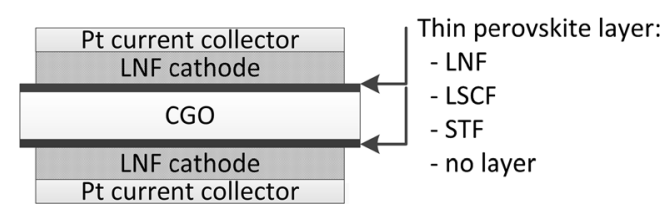

Fig. 1 Schematic representation of symmetrical cells 


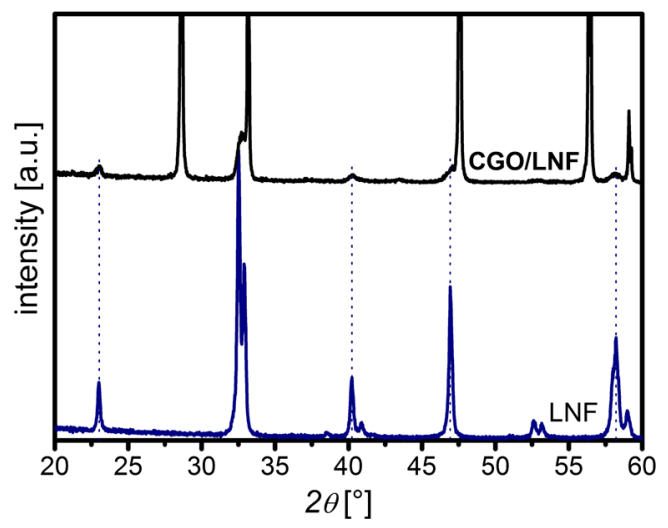

Fig. 2 XRD patterns of the bulk LNF and the LNF thin layer deposited on a CGO substrate and annealed at $1100{ }^{\circ} \mathrm{C}$ (dotted vertical lines match the peaks corresponding to the bulk and thin layer LNF)

force microscopy (AFM, Nanosurf EasyScan II) in contact mode. An AFM micrograph analysis was performed in Gwyddion program. Pellet density was measured using a fluid displacement method with kerosene as a working liquid. Symmetrical cells were characterized by the electrochemical impedance spectroscopy (EIS) using Solartron SI 1260 impedance analyzer coupled with SI 1287 electrochemical interface. The measurements were carried out in dry air in frequency range from $0.5 \mathrm{~Hz}$ to $1 \mathrm{MHz}$ and amplitude of $10 \mathrm{mV}$. The spectra were collected in the temperature range from 800 to $600{ }^{\circ} \mathrm{C}$ with $50{ }^{\circ} \mathrm{C}$ step.

\section{Results and discussion}

Structural characterization of prepared films

Thin perovskite layers spin coated on CGO substrates without depositing LNF cathode were investigated using XRD analysis in order to analyze their structure. The XRD measurements

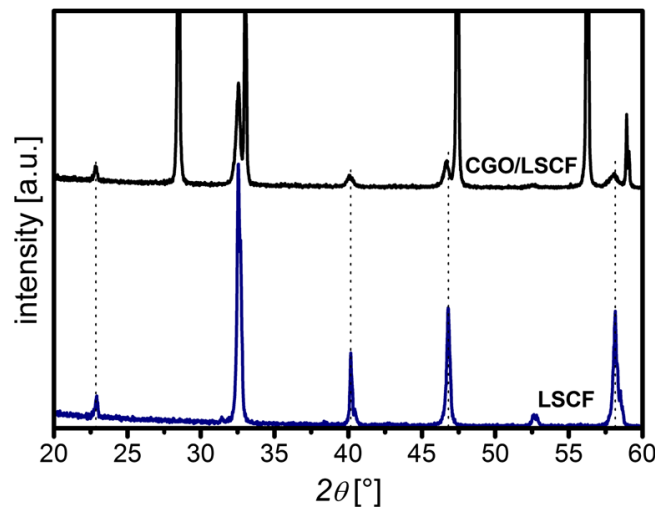

Fig. 3 XRD patterns of the bulk LSCF and the LSCF thin layer deposited on a CGO substrate and annealed at $1100{ }^{\circ} \mathrm{C}$ (dotted vertical lines match the peaks corresponding to the bulk and thin layer LSCF)



Fig. 4 XRD patterns of the bulk STF and the STF thin layer deposited on a CGO substrate and annealed at $1100{ }^{\circ} \mathrm{C}$ (dotted vertical lines match the peaks corresponding to the bulk and thin layer STF)

proved that LNF, LSCF, and STF films have the same crystallographic structure as bulk materials. Figure 2 shows XRD patterns for the bulk LNF and the LNF layer deposited on a CGO substrate and annealed at $1100{ }^{\circ} \mathrm{C}$. The observed reflections match the patterns, which were reported for the LNF and CGO compounds in Falcón et al. [29] and Zha et al. [30], respectively. Dotted vertical lines match the peaks corresponding to the bulk and thin layer LNF. No additional peaks were observed; thus, there are no secondary phases present in the layer within XRD sensitivity. Similarly, Fig. 3 shows XRD patterns for the bulk and thin film LSCF on CGO. Reflections observed for the bulk LSCF match the patterns reported in Tai et al. [25] and Kivi et al. [31]. Figure 4 shows the XRD diffraction patterns of the STF samples. The peaks observed for the bulk STF material are stronger than the ones observed for the other compounds. The reflections match the patterns, which were reported for the STF in Adler and Eriksson [32].

Deposited perovskite layers were visualized using AFM. The LSCF thin perovskite layer surface after deposition and

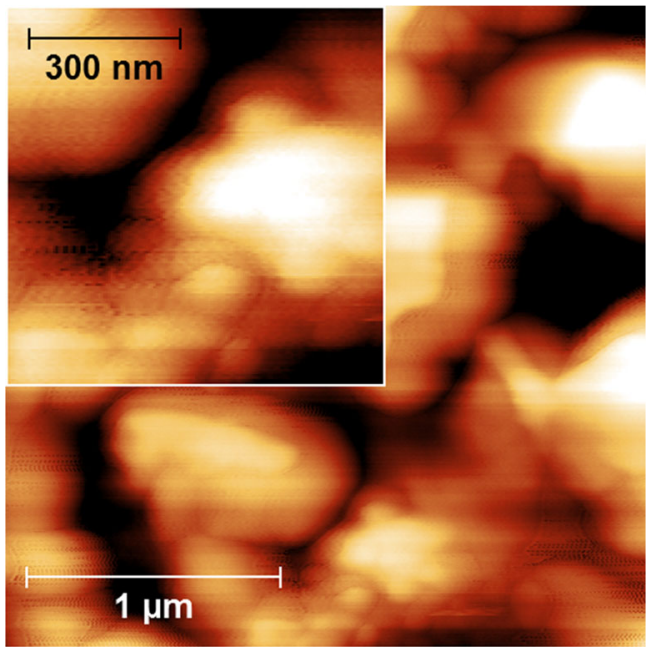

Fig. 5 AFM micrograph of the LSCF thin layer surface fired at $500{ }^{\circ} \mathrm{C}$. Inset shows magnification of grain-like structures 
firing at $500{ }^{\circ} \mathrm{C}$ is shown in Fig. 5. There are some grain-like structures visible although they are not observed for the LNF and STF samples (not shown in this paper). These structures are magnified in the inset.

Figure 6 shows AFM surface micrograms of the LNF (Fig. 6a, b), LSCF (Fig. 6c, d), and STF (Fig. 6e, f) thin perovskite layers. Pictures on the left (Fig. 6a, c, e) show the structures annealed at $800{ }^{\circ} \mathrm{C}$, while pictures on the right (Fig. 6b, d, f) show the structures annealed at $1100{ }^{\circ} \mathrm{C}$ (cathode sintering temperature). In case of the LNF layer annealed at $800{ }^{\circ} \mathrm{C}$ grain size is $180 \pm 14 \mathrm{~nm}$ and increases up to $290 \pm$ $30 \mathrm{~nm}$ once annealed at $1100^{\circ} \mathrm{C}$. The LSCF grains are smaller, i.e., $100 \pm 30$ and $205 \pm 13 \mathrm{~nm}$ once annealed at 800 and $1100^{\circ} \mathrm{C}$, respectively. In the case of the STF layer annealed at $800^{\circ} \mathrm{C}$, the grains are hardly distinguishable - their mean size is $70 \pm 17 \mathrm{~nm}$, while for the layer annealed at $1100{ }^{\circ} \mathrm{C}$, the grains grow up to $230 \pm 30 \mathrm{~nm}$. Clearly in the LNF layer, grain growth occurs faster than that in the other ones. It is also visible that the all studied samples annealed at $1100{ }^{\circ} \mathrm{C}$ have a well-defined microstructure.

Figures 7, 8, 9, and 10 show SEM images of the samples surfaces and cross sections. Figure $7 \mathrm{a}, \mathrm{b}$ shows the surfaces, while Fig. 7c, d the cross sections of the LNF thin layers. The layer annealed at $800{ }^{\circ} \mathrm{C}$ (Fig. 7a, c) has a low amount of residual pores, and it is difficult to distinguish it from the CGO substrate. The coat covers the substrate with about
Fig. 6 AFM micrographs of the thin perovskite layer surfaces. $\mathrm{LNF}$ annealed at a $800{ }^{\circ} \mathrm{C}, \mathbf{b}$ $1100^{\circ} \mathrm{C}$; LSCF annealed at c $800{ }^{\circ} \mathrm{C}, \mathbf{d} 1100{ }^{\circ} \mathrm{C}$; STF annealed at e $800{ }^{\circ} \mathrm{C}, \mathbf{f} 1100^{\circ} \mathrm{C}$

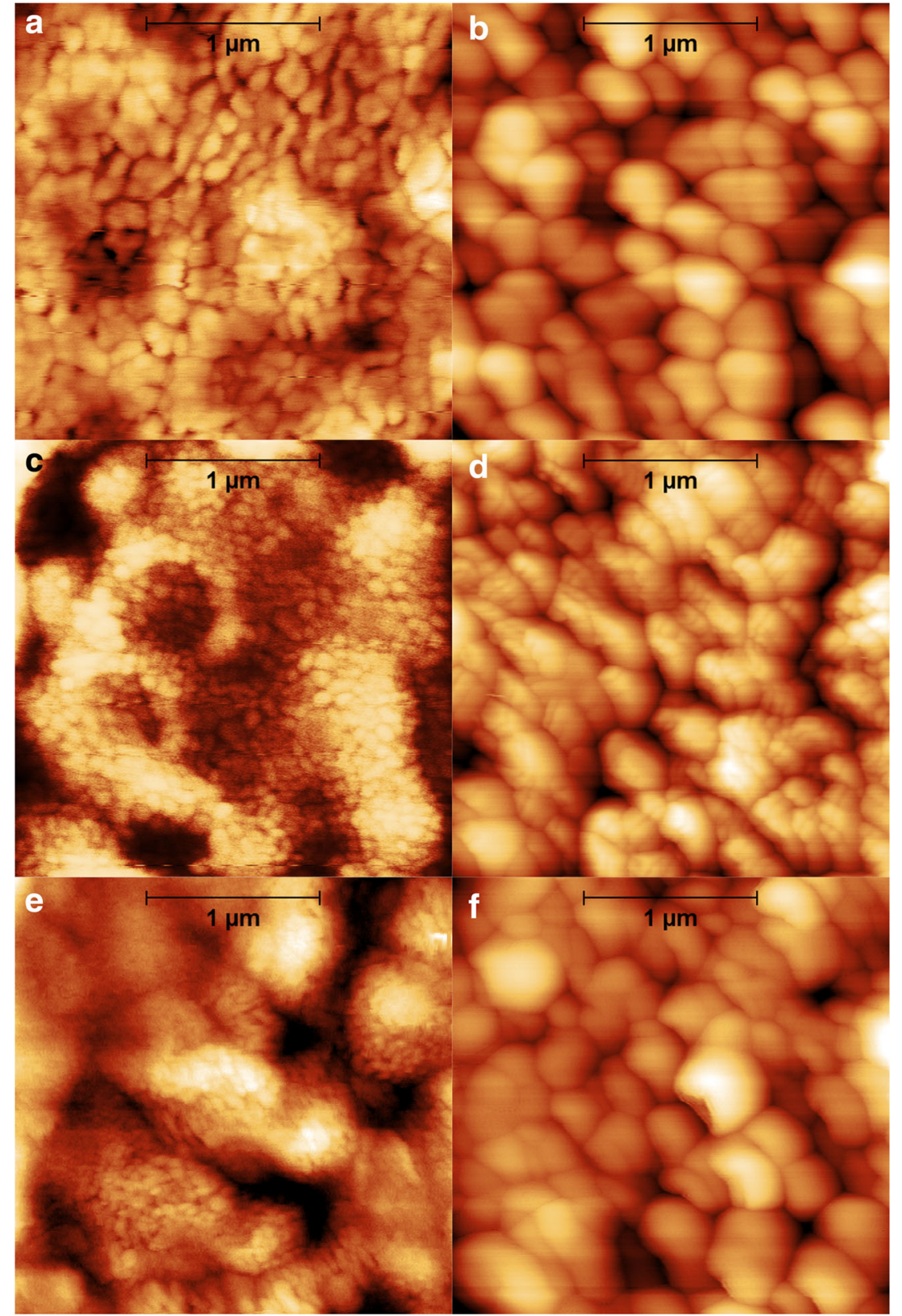


Fig. 7 SEM micrographs of the LNF thin layer surface annealed at a $800{ }^{\circ} \mathrm{C}$, b $1100{ }^{\circ} \mathrm{C}$ and cross section annealed at $\mathbf{c} 800{ }^{\circ} \mathrm{C}, \mathbf{d}$ $1100{ }^{\circ} \mathrm{C}$

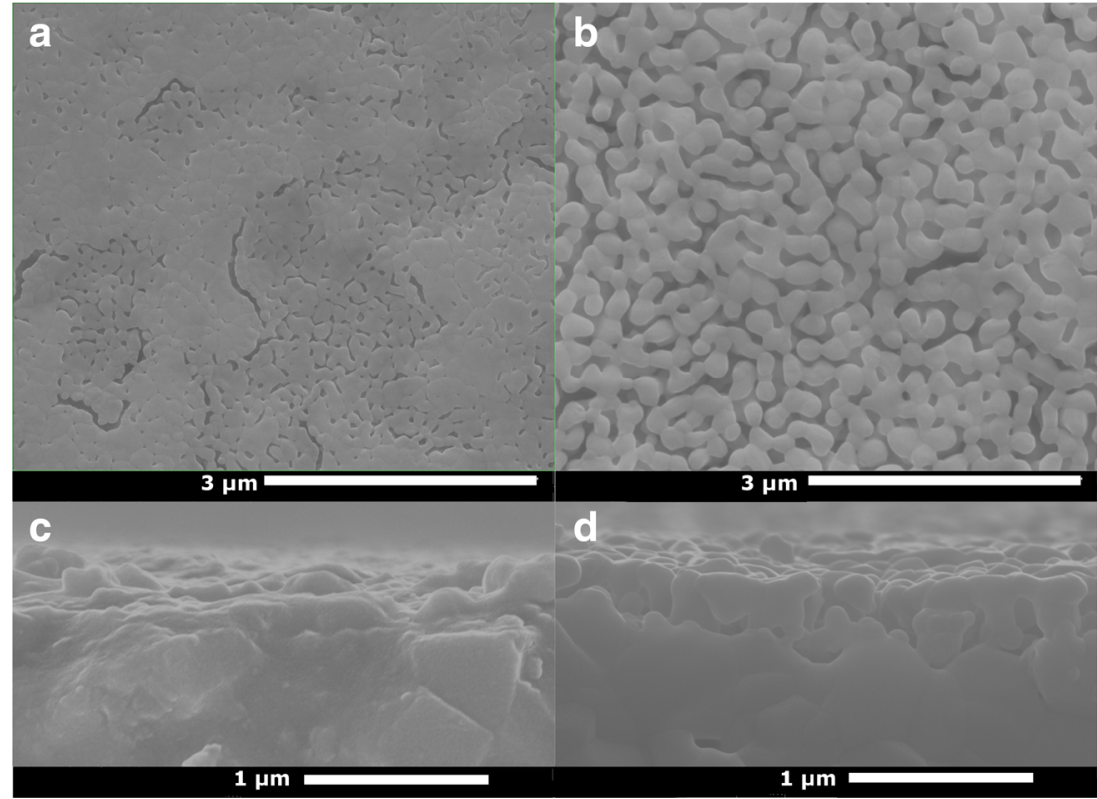

190-nm-thick thin layer reproducing the substrate roughness. On the other hand, the layer annealed at $1100{ }^{\circ} \mathrm{C}($ Fig. $7 \mathrm{~b}, \mathrm{~d})$ is clearly porous, and its structure is not determined by the substrate surface. As seen in the cross section, the layer is one to three grains thick $(\sim 300 \mathrm{~nm})$ although it is not dense. The grain contact with $\mathrm{CGO}$ is well established. Figure 8 shows surface of LSCF layer after annealing at $800{ }^{\circ} \mathrm{C}$ (Fig. 8a) and $1100{ }^{\circ} \mathrm{C}$ (Fig. 8b). This layer is clearly denser than other two, after annealing at both 800 and $1100{ }^{\circ} \mathrm{C}$, though there is some porosity visible in Fig. 8b. The STF layer after annealing at $800^{\circ}$ and $1100{ }^{\circ} \mathrm{C}$ is shown in Fig. 9a, b, respectively. Its structure is similar to LSCF, although more pores are visible after annealing at $1100^{\circ} \mathrm{C}$.

Large residual pores which occurred after annealing are connected with a deterioration of the layers at relatively high sintering temperatures. This phenomenon is caused by faster clustering of crystallites than growth of crystallites itself [33, 34]. Furthermore, high temperatures induce grain spheroidization, which leads to cracks and pores when film thickness is comparable or smaller than size of grains. Nevertheless, thin layers presented in this work adhere well to the CGO substrate, and no visual signs of delamination are observed.

Figure 10a, b shows the cathode-substrate interface without and with the (about $150 \mathrm{~nm}$ thick) LNF perovskite layer, respectively. As previously shown, the spin-coated layer annealed at $1100{ }^{\circ} \mathrm{C}$ is porous but exhibits a good contact with CGO. It is visible that the porous cathode deposited from the LNF paste without the thin perovskite layer has significantly smaller contact area. This may lead to the conclusion that depositing thin perovskite layer between cathode and substrate improves the contact area.

\section{Electrical characterization of symmetrical cells}

The symmetrical cathode/CGO/cathode cells were measured by means of electrochemical impedance spectroscopy. Introduction of the thin perovskite layer influences the
Fig. 8 SEM micrographs of the LSCF thin layer surface after annealing at $\mathbf{a} 800^{\circ} \mathrm{C}$ and $\mathbf{b}$ $1100{ }^{\circ} \mathrm{C}$




Fig. 9 SEM micrographs of the STF thin layer surface after annealing at $\mathbf{a} 800^{\circ} \mathrm{C}$ and $\mathbf{b}$ $1100{ }^{\circ} \mathrm{C}$

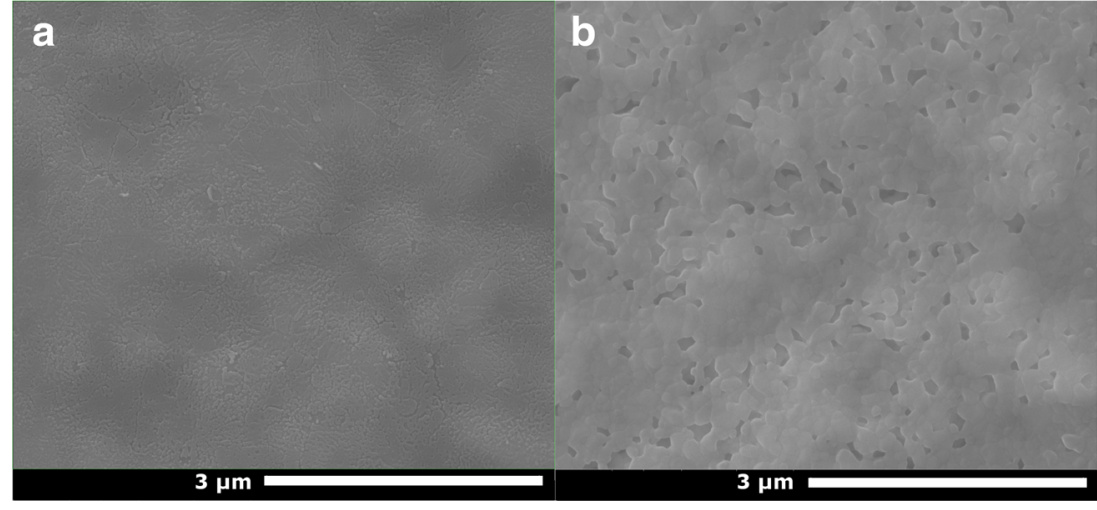

area-specific resistance (ASR). Examples of impedance spectra obtained at $800{ }^{\circ} \mathrm{C}$ for all four types of samples (without the thin perovskite layer and with the 160-nmthin layers of LNF, LSCF, and STF) with the apparent ohmic resistance subtracted are shown in Fig. 11. It is clearly visible that the introduction of the LSCF and LNF layer decreased total polarization resistance in contrast to the STF layer. The simplest equivalent circuit should represent at least three relaxation processes at a high $\left(10^{4} \mathrm{~Hz}\right)$, middle $\left(10^{2} \mathrm{~Hz}\right)$, and low $\left(10^{0} \mathrm{~Hz}\right)$ frequencies. However, the semicircles visible in the Nyquist plot are rather distorted, and the detailed analysis was not performed to avoid misinterpretations. Nevertheless, it can be noticed that the thin perovskite layer influences mainly the middle-frequency relaxation process, which is often associated with an interfacial resistance [35]. In
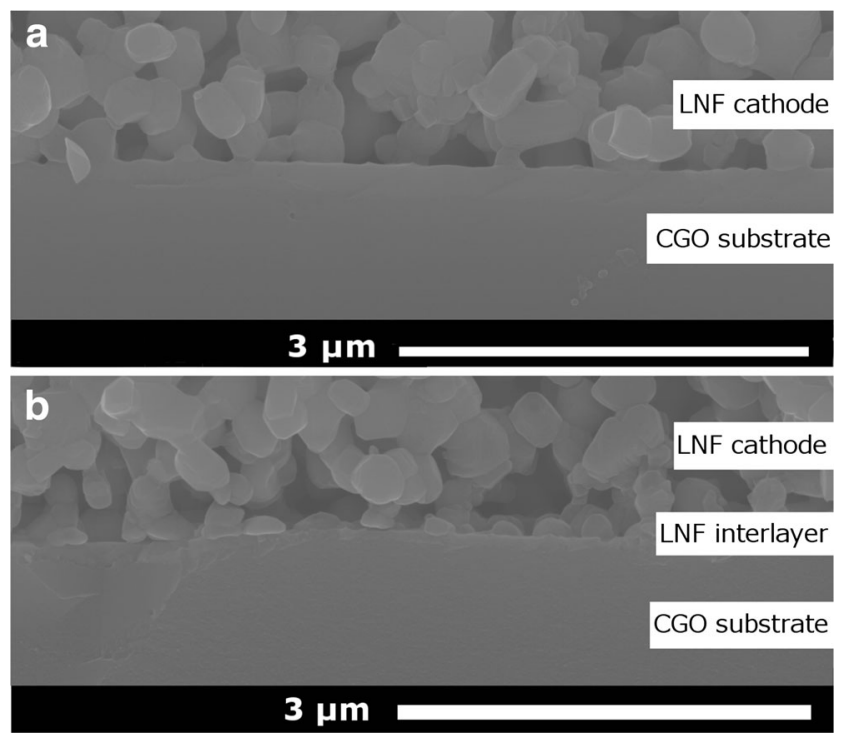

Fig. 10 SEM micrographs of the cross section of a cathode-substrate interface without (a) and with (b) the LNF thin perovskite layer order to evaluate the correct model, further studies using a distribution of relaxation times method will be carried.

Figure 12 shows Arrhenius plots for all four types of samples, i.e., the sample without thin perovskite layer and three with layers spin-coated six times, which produced layers with thickness of approximately $160 \mathrm{~nm}$. All samples except one with the STF layer demonstrate the ASR activation energy of $1.50 \mathrm{eV}$. The symmetrical cell with the STF thin perovskite layer has significantly higher activation energy, i.e., $1.68 \mathrm{eV}$. Such an increase indicates change in oxygen reduction reaction due to formation of a new, poorly catalytic, or nonconducting phase in the cathode/CGO interface or lower than LNF electronic conductivity of STF. Such a strong negative influence of STF itself is unlikely since it was shown to exhibit ASR values comparable to other cathode material like LSM or LNF [20] when deposited on YSZ electrolyte. Possibility of reaction between STF and LNF was subsequently confirmed by XRD analysis [36]. Introduction of the LSCF layer does not affect the activation energy, even though LSCF exhibits two orders of magnitude higher ionic conductivity than LNF. This indicates that such a thin layer does not significantly influence the oxygen reduction reaction mechanism.

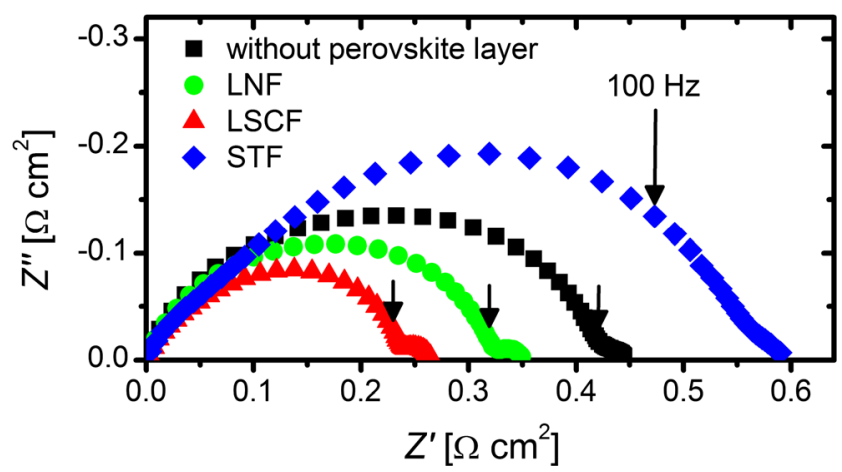

Fig. 11 Typical impedance spectra obtained at $800{ }^{\circ} \mathrm{C}$ for structures without or with the 160-nm-thin perovskite layers 




Fig. 12 Arrhenius plot of the ASR for structures without or with the 160nm-thin perovskite layers

Figure 13 shows the average ASR for symmetrical cells at $800{ }^{\circ} \mathrm{C}$ as a function of the perovskite layer thickness (the marked thickness taken as-deposited). Multiple samples were measured for each thickness. Symmetrical cells without thin perovskite layer exhibit the average ASR of $0.20 \Omega \mathrm{cm}^{2}$. Apart from STF, the introduction of the thin perovskite layer lowers the average ASR with the minimum obtained for the $160-\mathrm{nm}$ LSCF layer $\left(0.14 \Omega \mathrm{cm}^{2}\right)$. The inset shows single, not averaged measurements of samples with LSCF layer or without any. It can be seen that minimal ASR of cathode without perovskite layer equals $0.16 \Omega \mathrm{cm}^{2}$ which is a result comparable to systems with an additional layer; however, its reproducibility is poor. Distribution of ASR in the case of the samples with LSCF and LNF layer (LNF not shown) is significantly lowered which leads to conclusion that the introduction of the thin perovskite layer enables preparation of a more reproducible cathode-electrolyte contact. Introduction of $160-\mathrm{nm}$ LSCF layer lowers minimal ASR to $0.13 \Omega \mathrm{cm}^{2}$ with far greater consistency. Based on this and SEM images, it can be concluded that thin layer deposited by spin coating has much better contact with substrates and easily sinters with the later deposited porous cathode. The introduction of the layer thicker than $200 \mathrm{~nm}$ does not further improve the cathode/CGO interface. This support the observation that the introduced thin perovskite layer improves a physical contact between the cathode and CGO, what results in the enhancement of the oxygen transfer mechanism through the interface without any change in the oxygen reduction reaction mechanism. In the case of the STF layer, the significantly higher ASR and low cathode reproducibility are observed. Increasing the thickness of STF layer increases the ASR, which supports conclusion that STF creates poorly catalytic phase.

\section{Conclusion}

In this paper, the influence of the spin-coated thin perovskite layer between an LNF cathode and a CGO substrate on the
Fig. 13 The average ASR as a function of layer thickness for symmetrical cells at $800^{\circ} \mathrm{C}$ (solid lines are a guide to the eye only). In the inset, individual ASR results of reproducibility measurements for sample without an additional layer and with LSCF thin layer

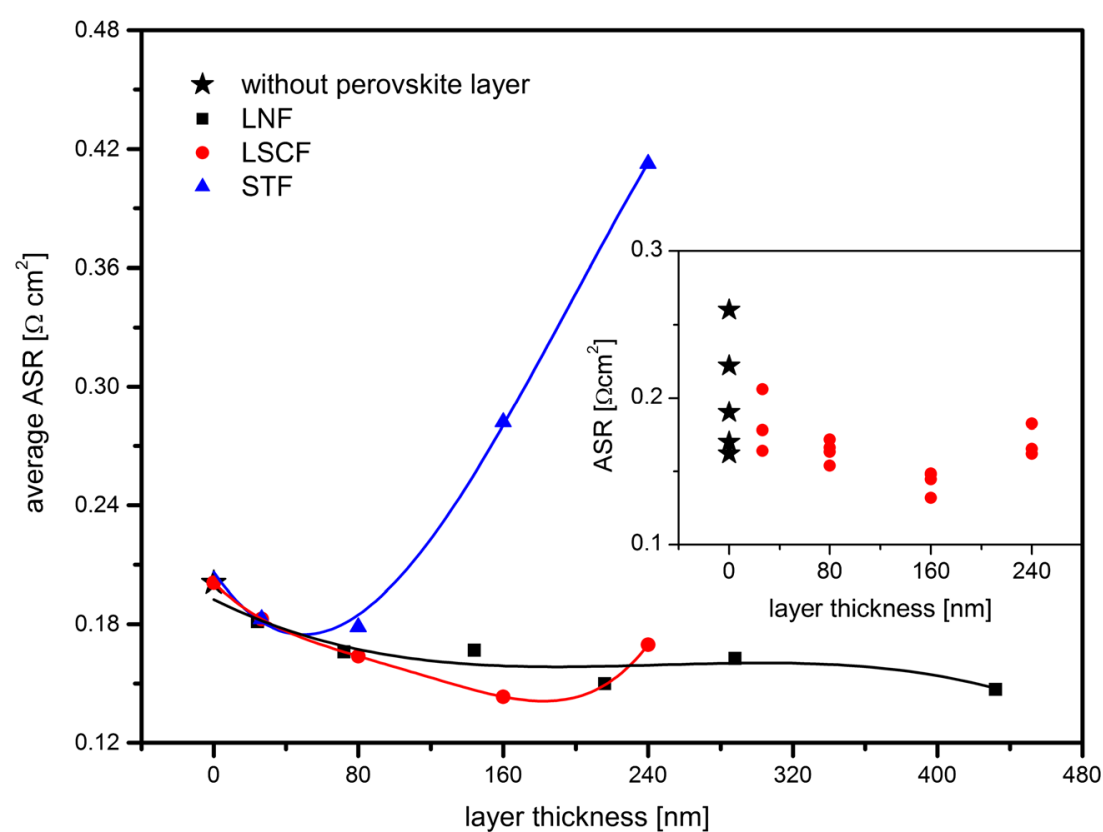


electrical properties of a symmetrical cells was investigated. Introduction of the LSCF layer improved the average areaspecific resistance by $29 \%$ at $800{ }^{\circ} \mathrm{C}$. In the case of the $\mathrm{LaNi}_{0.6} \mathrm{Fe}_{0.4} \mathrm{O}_{3-\delta}$ layer, the average ASR was improved by $27 \%$. Important aspect of thin layer introduction was the increase of cathode resistance reproducibility, visible for layers with initial thickness above $80 \mathrm{~nm}$. Based on SEM micrographs and the obtained activation energies of resistances, it was deduced that the thin perovskite layer improved the contact area and the oxygen ions transport between cathode and CGO without a significant change of the oxygen reduction reaction mechanism. The deposition of the approximately 160 -nm-thin perovskite layers is particularly advised when the cathode sintering temperature is low, since at these temperatures, the adhesion between the cathode and an electrolyte is limited. In the presented investigation, the STF layer significantly increased the polarization resistance of the cells, which may be associated with its reaction with LNF.

Acknowledgments This work is partly supported by project founded by National Science Centre Poland based on decision DEC-2012/05/B/ ST7/02153.

Open Access This article is distributed under the terms of the Creative Commons Attribution License which permits any use, distribution, and reproduction in any medium, provided the original author(s) and the source are credited.

\section{References}

1. Zhang X, Chan SH, Li G, Ho HK, Li J, Feng Z (2010) A review of integration strategies for solid oxide fuel cells. J Power Sources 195: 685-702

2. Zhao Y, Xia C, Jia L, Wang Z, Li H, Yu J, Li Y (2013) Recent progress on solid oxide fuel cell: Lowering temperature and utilizing non-hydrogen fuels. Int J Hydrog Energ 38(36):16498-16517

3. Ivers-Tiffée E, Weber A, Herbstritt D (2001) Materials and technologies for SOFC-components. J Eur Ceram Soc 21:1805-1811

4. Tsipis EV, Kharton VV (2008) Electrode materials and reaction mechanisms in solid oxide fuel cells: a brief review. I. Performance-determining factors. J Solid State Electrochem 12: 1039-1060

5. Tsipis EV, Kharton VV (2008) Electrode materials and reaction mechanisms in solid oxide fuel cells: a brief review. II. Electrochemical behavior vs. materials science aspects. J Solid State Electrochem 12:1367-1391

6. Tsipis EV, Kharton VV (2011) Electrode materials and reaction mechanisms in solid oxide fuel cells: a brief review. III. Recent trends and selected methodological aspects. J Solid State Electrochem 15: $1007-1040$

7. Adler SB (2004) Factors governing oxygen reduction reaction in solid oxide fuel cell cathodes. Chem Rev 104:4791-4843

8. Setevich CF, Mogni LV, Caneiro A, Prado FD (2012) Optimum cathode configuration for IT-SOFC using $\mathrm{La}_{0.4} \mathrm{Ba}_{0.6} \mathrm{Co}_{\mathrm{O} 3-\delta}$ and $\mathrm{Ce}_{0.9} \mathrm{Gd}_{0.1} \mathrm{O}_{1.95}$. Int J Hydrog Energ 37:4895-4901

9. McCoppin J, Young D, Reitz T, Maleszewski A, Mukhopadhyay S (2011) Solid oxide fuel cell with compositionally graded cathode functional layer deposited by pressure assisted dual-suspension spraying. J Power Sources 196:3761-3765

10. Huang B, Zhu X, Nie H, Niu Y, Li Y, Cheng N (2013) Comparison of the electrochemical properties of impregnated and functionally gradient $\mathrm{LaNi}_{0.6} \mathrm{Fe}_{0.4} \mathrm{O}_{3}-\mathrm{Gd}_{0.2} \mathrm{Ce}_{0.8} \mathrm{O}_{2}$ composite cathodes for solid oxide fuel cell. J Power Sources 235:20-28

11. Haanappel VAC, Jordan N, Mai A, Mertens J, Serra JM, Tietz F et al (2009) Advances in research, development, and testing of single cells at forschungszentrum jülich. J Fuel Cell Sci Technol 6:021302

12. Tanner CW, Fung KZ, Virkar AV (1997) The effect of porous composite electrode structure on solid oxide fuel cell performance. $\mathrm{J}$ Electrochem Soc 144(1):21-30

13. Rieu M, Sayers R, Laguna-Bercero MA, Skinner SJ, Lenormand P, Ansart $\mathrm{F}$ (2010) Investigation of graded $\mathrm{La}_{2} \mathrm{NiO}_{4+\delta}$ cathodes to improve SOFC electrochemical performance. J Electrochem Soc 157(4):B477-B480

14. Woolley RJ, Skinner SJ (2014) Functionally graded composite $\mathrm{LaNiO}$ and $\mathrm{LaNiO}$ solid oxide fuel cell cathodes. Solid State Ionics 255:1-5

15. Hildenbrand N, Boukamp B, Nammensma P, Blank D (2011) Improved cathode/electrolyte interface of SOFC. Solid State Ionics 192:12-15

16. Hildenbrand N, Nammensma P, Blank DHA, Bouwmeester HJM, Boukamp BA (2013) Influence of configuration and microstructure on performance of $\mathrm{La}_{2} \mathrm{NiO}_{4+\delta}$ IT-SOFC cathodes. J Power Sources 238:442-453

17. Dumaisnil K, Fasquelle D, Mascot M, Rolle A, Roussel P, Minaud S et al (2014) Synthesis and characterization of $\mathrm{La}_{0.6} \mathrm{Sr}_{0.4} \mathrm{Co}_{0.8} \mathrm{Fe}_{0.2} \mathrm{O}_{3}$ films for solid oxide fuel cell cathodes. Thin Solid Films 553:89-92

18. Stodolny MK, Boukamp BA, Blank DHA, van Berkel FPF (2011) $\mathrm{La}(\mathrm{Ni}, \mathrm{Fe}) \mathrm{O} 3$ stability in the presence of $\mathrm{Cr}$ species - solid-state reactivity study. J Electrochem Soc 158(2):B112-B116

19. Jiang SP, Chen X (2014) Chromium deposition and poisoning of cathodes of solid oxide fuel cells - a review. Int J Hydrog Energy 39:505-531

20. Molin S, Lewandowska-Iwaniak W, Kusz B, Gazda M, Jasinski P (2012) Structural and electrical properties of $\mathrm{Sr}(\mathrm{Ti}, \mathrm{Fe}) \mathrm{O}_{3-\delta}$ materials for SOFC cathodes. J Electroceram 28:80-87

21. Niwa E, Uematsu C, Miyashita E, Ohzeki T, Hashimoto T (2011) Conductivity and sintering property of $\mathrm{LaNi}_{1}{ }_{x} \mathrm{Fe}_{x} \mathrm{O}_{3}$ ceramics prepared by Pechini method. Solid State Ionics 201:87-93

22. Morán-Ruiz A, Vidal K, Laguna-Bercero MÁ, Larrañaga (2014) A effects of using $\left(\mathrm{La}_{0.8} \mathrm{Sr}_{0.2}\right)_{0.95} \mathrm{Fe}_{0.6} \mathrm{Mn}_{0.3} \mathrm{Co}_{0.1} \mathrm{O}_{3}$ (LSFMC), $\mathrm{LaNi}_{0.6} \mathrm{Fe}_{0.4} \mathrm{O}_{3-\delta}$ (LNF) and $\mathrm{LaNi}_{0.6} \mathrm{Co}_{0.4} \mathrm{O}_{3-\delta}$ (LNC) as contact materials on solid oxide fuel cells. J Power Sources 248:1067-1076

23. Montini T, Bevilacqua M, Fonda E, Casula MF, Lee S, Tavagnacco C, Gorte RJ, Fornasiero P (2009) Relationship between electrical behavior and structural characteristics in sr-doped $\mathrm{LaNi}_{0.6} \mathrm{Fe}_{0.4} \mathrm{O}_{3-\delta}$ mixed oxides. Chem Mater 21:1768-1774

24. Ullmann H, Trofimenko N, Tietz F, Stöver D, Ahmad-Khanlou A (2000) Correlation between thermal expansion and oxide ion transport in mixed conducting perovskite-type oxides for SOFC cathodes. Solid State Ionics 138(1-2):79-90

25. Tai LW, Nasrallah MM, Anderson HU, Sparlin DM, Sehlin SR (1995) Structure and electrical properties of $\mathrm{La}_{1-\mathrm{x}} \mathrm{Sr}_{\mathrm{x}} \mathrm{Co}_{1-\mathrm{y}} \mathrm{Fe}_{\mathrm{y}} \mathrm{O}_{3}$. Part 2. The system $\mathrm{La}_{1-\mathrm{x}} \mathrm{SrxCo}_{0.2} \mathrm{Fe}_{0.803}$. Solid State Ionics 76:273-283

26. Chourashiya MG, Bharadwaj SR, Jadhav LD (2010) Synthesis and characterization of electrolyte-grade $10 \% \mathrm{Gd}$-doped ceria thin film/ ceramic substrate structures for solid oxide fuel cells. Thin Solid Films 519(2):650-657

27. Chiba R, Tabata Y, Komatsu T, Orui H, Nozawa K, Arakawa M et al (2008) Property change of a $\mathrm{LaNi}_{0.6} \mathrm{Fe}_{0.4} \mathrm{O}_{3}$ cathode in the initial current loading process and the influence of a ceria interlayer. Solid State Ionics 178(31-32):1701-1709 
28. Jasinski P, Molin S, Gazda M, Petrovsky V, Anderson HU (2009) Applications of spin coating of polymer precursor and slurry suspensions for solid oxide fuel cell fabrication. J Power Sources 194:10-15

29. Falcón H, Goeta AE, Punte G, Carbonio RE (1997) Crystal structure refinement and stability of $\mathrm{LaFe}_{x} \mathrm{Ni}_{1-x} \mathrm{O}_{3}$ solid solutions. J Solid State Chem 133:379-385

30. Zha S, Xia C, Meng G (2003) Effect of Gd (Sm) doping on properties of ceria electrolyte for solid oxide fuel cells. J Power Sources 115:44-48

31. Kivi I, Aruväli J, Kirsimäe K, Heinsaar A, Nurk G, Lust E (2013) Changes in LSC and LSCF cathode crystallographic parameters measured by electrochemical in situ high-temperature XRD. ECS Trans 57:1841-1849

32. Adler P, Eriksson S (2008) Structural properties, Mössbauer spectra, and magnetism of perovskite-type oxides $\mathrm{SrFe}_{1-\mathrm{x}} \mathrm{Ti}_{\mathrm{x}} \mathrm{O}_{3-\mathrm{y}} . \mathrm{Z}$ Anorg Allg Chem 626:118-124
33. Díaz-Parralejo A, Ortiz AL, Caruso R (2010) Effect of sintering temperature on the microstructure and mechanical properties of $\mathrm{ZrO}_{2}-3$ mol\% $\mathrm{Y}_{2} \mathrm{O}_{34}$ sol-gel films. Ceram Int 36:2281-2286

34. Oh EO, Whang CM, Lee YR, Lee JH, Yoon KJ, Kim BK, Son JW, Lee JH, Lee HW (2012) Thin film yttria-stabilized zirconia electrolyte for intermediate-temperature solid oxide fuel cells (IT-SOFCs) by chemical solution deposition. J Eur Ceram Soc 32:1733-17414

35. Baumann FS, Fleig J, Habermeier HU, Maier J (2006) Impedance spectroscopic study on well-defined $(\mathrm{La}, \mathrm{Sr})(\mathrm{Co}, \mathrm{Fe}) \mathrm{O}_{3-\delta}$ model electrodes. Solid State Ionics 177:1071-1081

36. Chrzan A, Gazda M, Szymczewska D, Jasinski P (2014) Interaction of $\mathrm{SrTi}_{0.65} \mathrm{Fe}_{0.35} \mathrm{O}_{3-\delta}$ with $\mathrm{LaNi}_{0.6} \mathrm{Fe}_{0.4} \mathrm{O}_{3-\delta}, \mathrm{La}_{0.6} \mathrm{Sr}_{0.4} \mathrm{Co}_{0.2} \mathrm{Fe}_{0.8} \mathrm{O}_{3-\delta}$ and $\mathrm{Ce}_{0.8} \mathrm{Gd}_{0.2} \mathrm{O}_{2-\delta}$. Procedia Eng 98:101-104 